\title{
Transcription Regulator Protein BACH2
}

National Cancer Institute

\section{Source}

National Cancer Institute. Transcription Regulator Protein BACH2. NCI Thesaurus. Code C97236.

Transcription regulator protein $\mathrm{BACH} 2(841 \mathrm{aa}, \sim 93 \mathrm{kDa})$ is encoded by the human $\mathrm{BACH} 2$ gene. This protein is involved in transcriptional modulation. 